\title{
Resiprokal Menggunakan Simpai Memperbaiki Belajar Passing Atas Bola Voli
}

\author{
Sabaruddin Yunis Bangun ${ }^{a}$ \\ ${ }^{a}$ Fakultas Ilmu Keolahragaan, Universitas Negeri Medan, Medan, Indonesia
}

*Corresponding author: unisbgn@unimed.ac.id

\section{A R T I C LE INFO}

\section{Article history:}

Received 21 April 2017

Received in revised form 25 April 2017

Accepted 29 April 2017

\section{Keywords:}

Using Reciprocal Media Hoop

\begin{abstract}
A B S T R A C T
The purpose of this study was to determine whether through the implementation of reciprocal teaching style by using the media to improve learning outcomes loops passing over a volleyball student-SMP 40 Medan. The research method used is descriptive quantitative approach to the type of classroom action research. In this case the researchers used a descriptive statistical analysis. For example, to find the mean, percentage of student success. The results of this study is to use Media Reciprocal teaching style hoops give effect to the improvement of learning outcomes of students Passing the Volleyball Field SMPN 40 academic year 2015/2016. Value of the average percentage of students in the pre-test was $51 \%$ (Not Completed), the post-test I mean value increased to $56.83 \%$ of students (Not Completed), and the implementation of the post-test II the average student has reached $73.5 \%$ (Completed).
\end{abstract}

\section{Pendahuluan}

Pendidikan merupakan suatu kebutuhan yang sangat penting bagi setiap manusia. Pendidikan sangat penting artinya bahwa tanpa pendidikan manusia akan sulit untuk maju dan berkembang sesuai dengan tuntutan zaman. Dengan demikian pendidikan harus benar-benar diarahkan agar dapat menghasilkan manusia yang berkualitas serta mampu bersaing karena memiliki akal pikiran serta budi pekerti yang luhur dan moral yang baik.

Dalam mengahadapi tantangan IPTEK bangsa Indonesia perlu memiliki warga Negara yang bermutu dan berkualitas tinggi. Karena kualitas seseorang akan terlihat jelas dalam bentuk kemampuan dan kepribadianya pada saat orang tersebut berhadapan dengan tantangan atau harus mengatasi suatu masalah sampai masalah tersebut dapat dipecahkan dengan baik. Oleh sebab itu pendidikan memegang peranan penting dalam usaha meningkatkan sumber daya manusia mulai saat ini sampai masa yang akan datang.

Dengan diberlakukanya Kurikulum Tingkat Satuan Pendidikan (KTSP) di sekolah, menuntut guru dan siswa untuk bersikap aktif, kreatif, inovatif dan kompetitif dalam menanggapi setiap pelajaran yang diajarkan. Maka setiap siswa harus dapat memanfaatkan ilmu yang di perolehnya dari setiap pelajaran dan memanfaatkanya dalam kehidupan sehari-hari. Peran guru adalah sebagai fasilisator dalam setiap kegiatan pelajaran yang akan diajarkan kepada siswa dan bukan sumber utama pembelajaran.

Untuk menumbuhkan dan meningkatkan sikap aktif, kreatif, inovatif dan kompetitif dari siswa sebenarnya tidaklah mudah. Karena kenyataanya guru dianggap sebagai sumber belajar yang paling utama dan yang paling benar, dan memposisikan siswa sebagai pendengar ceramah guru. Akibatnya proses belajar mengajar cenderung membosankan dan menjadikan siswa malas untuk belajar. Sikap anak didik yang pasif ternyata tidak hanya terjadi pada mata pelajaran tertentu saja tetapi pada hampir semua mata pelajaran termasuk penjas.

Berkaitan dengan masalah tersebut pada pembelajaran penjas juga ditemukan keragaman masalah yaitu sebagai berikut:
1) Keaktifan siswa dalam mengikuti pembelajaran masih belum terlihat dengan jelas.

2) Para siswa jarang mengajukan pertanyaan walaupun guru sering meminta agar siswa bertanya jika ada hal-hal yang belum jelasatau kurang paham.

3) Keaktifan dalam mengerjakan soal-soal latihan pada proses pembelajaran masih kurang.

4) Kurangnya keberanian siswa untuk mengerjakan soal didepan kelas Berdasarkan hasil observasi peneliti di SMPN 40 Medan, diperoleh kesimpulan bahwa nilai kemampuan siswa dalam melakukan passing atas bola voli masih rendah. Ini disebabkan karena guru bidang studi pendidikan jasmani masih menerapkan pembelajaran dengan metode konvensional yaitu guru menyampaikan materi pelajaran dengan menggunakan media buku pelajaran atau buku paket dari sekolah, papan tulis, kapur tulis untuk berimajinasi atau berkhayal dari media tanpa penalaran logis misalnya seperti kemampuan membuktikan atau memperlihatkan suatu konsep yang nyata pada saat pembelajaran berlangsung.

Melalui penerapan gaya mengajar resiprokal dengan menggunakan media simpai sebagai alat bantu dalam proses belajar mengajar sangat membantu karena siswa dalam meningkatkan hasil belajar passing atas dalam permainan bola voli dan meningkatkan semangat siswa untuk melakukan pembelajaran. Alasan peneliti menerapkan gaya mengajar resiprokal dengan menggunakan media simpai pada pembelajaran passing atas bola voli di SMPN 40 Medan adalah untuk memperbaiki hasil belajar passing atas bola voli di SMPN 40 Medan karena melihat kondisi di sekolah yang pada kenyatanya masih banyak siswa yang kurang bersemangat dalam melakukan pembelajaran. Jadi untuk memperbaiki hasil belajar passing atas bola voli di SMPN 40 Medan peneliti ingin menerapkan gaya mengajar resiprokal dengan menggunakan media simpai.

Gaya mengajar resiprokal ini dimulai dengan memperhatikan perubahan yang lebih besar dalam suatu keputusan yang berasal dari guru kepada siswa. Seiring dengan itu (Supandi, 1992: 31) menyatakan bahwa "pada dasarnya gaya mengajar ini merupakan teori umpan balik atau feedback." Seluruh siswa bertanggung jawab mengobservasi teman dan memberikan umpan balik serta memberikan koreksi dari setiap gerakan 
yang dilakukan. Dengan kebebasan yang diberikan oleh guru, siswa dituntut lebih mandiri dan kreatif serta mempunyai rasa tanggung jawab yang besar karena peranan guru sangat diminimalisir dalam gaya ini. Seiring dengan itu (Moston, 19940: 30) mengemukakan bahwa: Pelaksanaan gaya resiprokal secara umum: Setiap kali guru akan memberikan pelajaran, guru harus memulai dengan memberikan peragaan dan menguraikan cara pelaksanaan skill itu dan mengklarifikasi lembar tugasnya.

Dari pendapat diatas tentang gaya mengajar dapat diartikan sebagai usaha-usaha yang dilakukan guru untuk merangsang dan mempercepat proses perubahan perilaku siswa. Secara garis besarnya prosedur gaya mengajar ini mengikuti langkah-langkah sebagai berikut: seperti yang diutarakan (Supandi, 1992: 32). (1) Siapkan lembar kerja atau worksheet yang memuat deskripsi gerakan atau pokok bahsan yang harus dilakukan oleh siswa. Siapkan dalam jumlah yang cukup memadai. Deskripsi akan lebih jelas bila disertai dengan gambar-gambar. (2) Bentuklah kelas menjadi formasi berpasangan yang akan berperan sebagai pelaku dan pengamat. Pelaku melakukan atau melaksanakan gerakan atau pokok bahasan yang tertera dalam lembar kerja. Siswa pengamat mengamati proses pelaksanaan pelaku, mencatat kekuranganya dalam lembar kerja dan menyampaikan hasil pengamatanya kepada pelaku setelah selesai melakukan gerakan-gerakan tersebut. Hasil pengamatanya itu kemudian didiskusikan pasangan tersebut. (3) Berganti peran, yang tadinya pelaku menjai pengamat dan sebaliknya.

Gaya mengajar ini juga mempunyai keuntungan dan kelemahan. Keuntungan dari gaya ini antara lain: a) Memberikan umpan balik seketika tanpa ditunda-tunda yang mempunyai pengaruh nyata dalam terhadap proses belajar siswa. Umpan balik ini berupa tentang apa yang diperbuat baik yang benar atau yang salah b) Dapat mengembangkan cara kerja dalam tim kecil sehingga aspek sosialnya berkembang c) Meningkatkan proses belajar mengajar cara mengamati secara sistematik gerakan atau pokok bahasan dari teman. Pada dasarnya, mengamati kegiatan belajar teman itu merupakan suatu proses kegiatan belajar mengajar juga.

Kelemahan gaya resiprokal: a) Sering menimbulkan situasi yang emosional antara pelaku dan pengamat yang disebabkan pengamat berlaku berkelebihan dalam menyampaikan informasi yang bersangkutan. Perilaku yang berkelebihan itu antara lain menyampaikan dengan nada mengejek, menggurui, menghakimi, atau menganggap teman lebih rendah. b) Pada umumnya pelaku tidak tahan terhadap kritik siswa pengamat sehubung dengan hasil belajar yang pernah dilakukan sebelumnya. Siswa pelaku tidak mau terima hasil pengamatan temanya. Situasi ini sering menimbulkan ketegangan antara siswa pelaku dengan siswa pengamat. c) Sering juga terjadi pasangan ini justru memantapkan suatu prilaku yang salah, disebabkan karena mereka salah menafsirkan deskripsi gerakan atau pokok bahasan yang tertera dalam lembar kerja.

Permainan bola voli adalah permainan yang dimainkan oleh dua regu yang berjumlah enam orang setiap regunya. Dalam permainan bola voli terdapat beberapa teknik dasar dalam permainan bola voli yaitu passing, servis, smash, dan blocking. Salah satu teknik dasar yang harus dikuasai untuk dapat bermain bola voli dengan baik adalah teknik dasar passing. Hal ini sesuai dengan yang dikemukakan oleh (Durrwachter, 1986: 40) yaitu: "Tahap awal permainan bola voli sudah memadai apabila pemain sudah menguasai teknik dasar yang terdiri dari sevis dan passing." Pendapat ini menegaskan bahwa seseorang bila ingin dapat bermain voli dengan baik harus dapat menguasai teknik passing dengan benar dan juga dapat melakukan servis dengan baik. Bila teknik dasar passing ini tidak dikuasai dengan baik, maka seseorang tidak akan dapat bermain bola voli.

Teknik pelaksanaan passing atas adalah sebagai berikut : "Sikap persiapan mengambil sikap normal, tubuh harus dalam keadaan seimbang yang labil salah satu kaki berada didepan yang lainya, lutu ditekuk, badan agak condong sedikit kedepan dengan tangan siap didepan dada. Pada saat melakukan passing segeralah menempatkan diri dibawah bola dan tangan diangkat keatas kira-kira setinggi dahi, jari-jari tangan secara keseluruhan membentuk satu bulatan, jari-jari direnggangkan sedikit satu dengan yang lain, dan kedua ibu jari membentuk satu sudut".
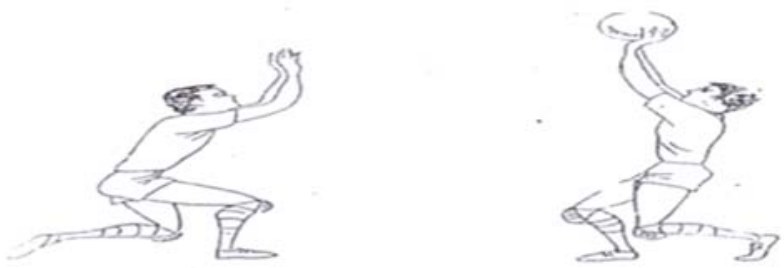

Gambar 1 : Sikap passing atas

Sikap perkenaan bola pada jari diruas pertama dan kedua, terutama ruas pertama dari ibu jari. Pada saat jari disentuhkan pada bola maka jarijari agak ditegangkan sedikit dan pada saat itu juga gerakan pergelangan tangan, lengan kearah depan atas eksplosif.

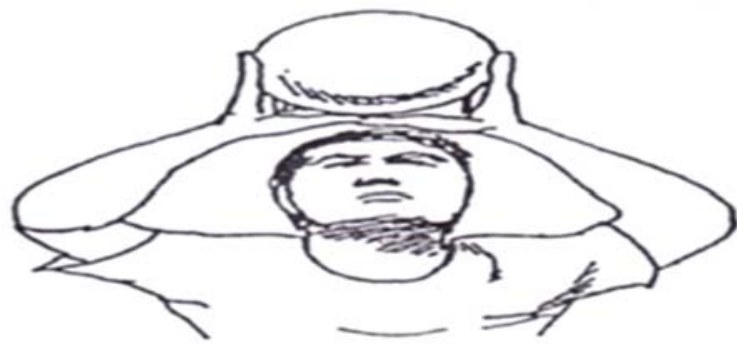

Gambar 2 : Sikap tangan passing atas

Begitu juga dalam pelaksanaan teknik passing atas pada sikap akhir, sikap akhir setelah bola berhasil dipassing, maka lengan harus lurus sebagai suatu gerakan lanjutan diikuti dengan badan dan lankah kaki kedepan agar koordinasi tetap terjaga baik. Gerakan tangan, pergelangan tangan, lengan dan kaki harus merupakan gerakan yang harmonis".

Sikap permulaan: Pada saat permulaan, siswa bergerak ke arah datangnya bola, tepat dibawah bola. Siapkan posisi kemudian bahu sejajar sasaran dan kaki merenggang santai kemudian bengkokkan sedikit lengan, kaki dan pinggul dan melihat melalui jendela yang dibentuk tangan dan di ikuti kesasaran bola.

Saat memainkan bola: Pada saat bola dimainkan, siswa menerima bola pada bagian belakang bawah bola dengan persendian teratas dari jari dan ibu jari dengan meluruskan lengan dan kaki kearah sasaran denagn mengikuti memindahkan berat badan kearah sasaran dan arahkan bola sesuai ketinggian yang diinginkan.

Gerakan lanjutan: Sebagai gerak lanjutan baik lengan harus diluruskan sepenuhnya kemudian arahkan bola kesasaran dan pinggul bergerak maju kearah sasaran dan kemudian pindahkan berat badan kearah sasaran dan bergerak kearah umpan. Hasil passing atas ini akan lebih tepat lagi mengenai sasaranya, apabila posisi tubuh mengarah kepada anak yang menerimanya.

Media sering juga disebut dengan perangkat lunak yang bukan saja memuat pesan atau bahan ajar untuk disalurkan melalui alat tertentu, tetapi juga dapat merangsang pikiran, perasaan dan kemauan siswa sehingga dapat mendorong terjadinya proses belajar pada dirinya. Dengan demikian media harus digunakan secara kreatif dalam arti guru harus menyiapkan dan merancang dengan tepat agar memungkinkan siswa belajar lebih banyak, mencamkan lebih baik apa yang dipelajari dan meningkatkan performa mereka sesuai dengan tujuan yang ingin dicapai. Disinilah guru dituntut lebih berhati-hati dalam memilih dan menetapkan media yang tepat dalam proses pembelajaran.

Manfaat media dalam proses pembelajaran secara umum adalah memperlancar proses interaksi antara guru dan siswa dan untuk membantu 
siswa belajar secara optimal. Internet (karya Individual) media merupakan alat saluran komunikasi. Media berasal dari bahasa Latin dan merupakan bentuk jamak dari kata "medium" yang secara harfiah berarti "perantara", yaitu perantara sumber pesan (a source) dengan penerima pesan (a receiver), seperti film, televisi, diagram, bahan tercetak, komputer, dan instruktur. Dalam proses pembelajaran terdapat pesanpesan yang harus dikomunikasikan. Pesan tersebut biasanya merupakan isi dari suatu topik pembelajaran. Pesan-pesan ini disampiakan oleh guru kepada siswa melalui suatu media dengan menggunakan prosedur pembelajaran tertentu yang disebut metode.

Pembelajaran yang menggunakan dengan bantuan media simpai dimaksudkan untuk memperbaiki hasil belajar passing atas dan merangsang siswa untuk belajar lebih efektif. Dengan adanya media ini siswa tidak akan merasa bosan dalam melaksanakan pembelajaran.

Media simpai yang digunakan adalah terbuat dari kayu rotan berbentuk bulat atau ban luar sepeda dengan ukuran $75 \mathrm{~cm}$. media ini digunakan dengan cara simpai, diletakan diatas net atau sejajar net dengan diikat diantara dua tiang. Simpai yang digunakan berjumlah 5 simpai yang jarak antara simpai ke simpai adalah $87,5 \mathrm{~cm}$ yang di pasang secara sejajar. Seperti gambar dibawah ini :

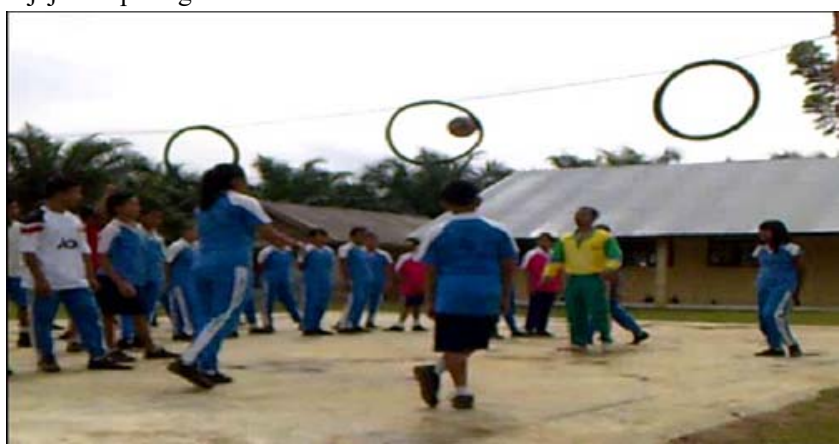

Gambar 3 : Sasaran passing atas dengan media simpai.

Tujuan penelitian untuk mengetahui apakah melalui penerapan gaya mengajar resiprokal dengan menggunakan media simpai dapat memperbaiki hasil belajar passing atas bola voli pada siswa SMPN 40 Medan.

Manfaat penelitian adalah menambah wawasan, pengetahuan dan untuk memperbaiki hasil belajar passing atas bola voli melalui penerapan gaya mengajar resiprokal dengan menggunakan media simpai pada pelajar dalam pembelajaran pendidikan Jasmani di sekolah.

\section{Metode}

Penelitian ini menggunakan metode penelitian deskriptif pendekatan kuantitatif dengan jenis penelitian tindakan kelas. Dalam hal ini peneliti menggunakan analisis statistik deskriptif. Misalnya, mencari nilai rerata, presentase keberhasilan belajar, dan lain-lain. Adapun subyek penelitian adalah siswa kelas VIII SMPN 40 Medan, dari 6 kelas di ambil secara acak 1 kelas sebagai perwakilan sampel. Penelitian ini dilaksanakan pada 14 s/d 21 Maret tahun 2016 selama 2 minggu (2x pertemuan) dengan pertimbangan mengikuti kurikulum yang ada di sekolah.

Sesuai dengan jenis penelitian ini, yaitu penelitian tindakan kelas maka penelitian terdiri dari beberapa tahap yang berupa siklus sebagai berikut: Siklus 1, (a) Tahap Perencanaan Tindakan (Alternatif Pemecahan I), (b) Tahap Pelaksanaan Tindakan I, (c) Observasi I, (d) Evaluasi I, (f) Tahap Repleksi I, hasil refleksi ini digunakan sebagai dasar untuk tahap perencanaan siklus II. Siklus II, (a) Tahap Perencanaan Tindakan II (Alternatif Pemecahan II), kegiatan lain yang digunakan adalah menyusun kembali lembar observasi dan menyusun tes hasil belajar II. (b) Pelaksanaan Tindakan II, (c) Observasi II, (d) Evaluasi II, (e) Refleksi II, Seluruh data yang diambil dianalisis dan ditarik kesimpulan dari tindakan perbaikan yang telah dilakukan. Dapat ditarik kesimpulan hasil belajar siswa dari siklus ke siklus.
Desain penelitian yang dilakukan adalah:

Tabel 1. Pre test - Post test Design

\begin{tabular}{|c|c|c|}
\hline Tes Awal & Perlakuan & Tes Akhir \\
\hline Pre test & $\begin{array}{c}\text { Gaya Mengajar Resiprokal } \\
\text { Dengan Menggunakan Media } \\
\text { Simpai }\end{array}$ & Post test \\
\hline
\end{tabular}

Instrumen Penelitian yang digunakan dalam penelitian ini adalah penilaian secara proses dengan portofolio dan penilaian hasil kemampuan passing atas bola voli. Aspek penilaian dan besaran skor yang diperoleh dari setiap item disesuaikan berdasarkan kriteria-kriteria yang telah dibuat, dimana jumlah skor tertinggi adalah 4 dan terendah adalah 1, dan total skor maksimum dari semua item adalah 12. Alat/fasilitas yang digunakan yaitu: 1) Lapangan voli ( $\mathrm{L}=9 \mathrm{M}, \mathrm{P}=18 \mathrm{M})$, 2) Bola Voli 5 buah, 3) Pluit, 4) Stopwatch, 5) Simpai (Rotan/Ban sepeda) ukuran diameter $75 \mathrm{~cm} .5$ buah.

Analisis data penelitian ini dilakukan dalam dua analisis, yakni data kuantitatif dan data kualitatif. 1) Reduksi Data, Proses reduksi data dilakukan dengan cara menyeleksi, menyederhanakan dan mentransformasikan data yang telah disajikan dalam transkrip catatan lapangan. Kegiatan reduksi data ini bertujuan untuk melihat kesalahan atau kekurangan siswa dalam pelaksanaan tes dan tindakan apa yang dilakukan untuk perbaikan kesalahan tersebut. 2) Paparan Data, dalam kegiatan ini data yang diperoleh dari hasil belajar siswa dipaparkan dalam bentuk tabel dalam bentuk rumus yang telah ditetapkan. Untuk mengetahui persentase kemampuan siswa digunakan rumus :

$$
\mathrm{PPH}=\frac{B}{N} X 100 \%
$$

\section{Keterangan: \\ PPH : Persentase Penilaian Hasil \\ B : Skor yang diperoleh \\ $\mathrm{N} \quad$ : Skor total maksimal (12) \\ Dengan kriteria : \\ $0 \%<\mathrm{KKM}<65 \%$ \\ $65 \% \leq \mathrm{KKM} \leq 100 \%$ \\ = Siswa belum tuntas dalam belajar $=$ Siswa sudah tuntas dalam belajar \\ (Sumber: Guru Penjas SMP Negeri 40 Medan).}

Dari uraian diatas dapat diketahui siswa yang belum tuntas dalam belajar dan siswa yang sudah tuntas dalam belajar secara individu. Selanjutnya dapat juga diketahui apakah ketuntasan belajar siswa secara klasikal dapat tercapai, dilihat dari persentase siswa yang sudah tuntas dalam belajar dapat dirumuskan sebagai berikut :

$$
\mathbf{P K K}=\frac{\text { Banyak siswa yang } p p h \geq 65 \%}{\text { Banyak siswa keseluruhan }}
$$

Keterangan :

PKK : Persentase Ketuntasan Klasikal

\section{Hasil dan diskusi}

\section{Hasil}

\section{Pelaksanaan Siklus I}

Merencanakan tindakan berupa membuat Rencana Pelaksanaan Pembelajaran (RPP) membuat kegiatan melalui penerapan gaya mengajar resiprokal dengan menggunakan media simpai. Tindakan, materi passing atas bola voli yang dilaksanakan dengan menerapkan gaya mengajar resiprokal dengan menggunakan media simpai yang dilaksanakan selama 2 jam pelajaran $(2 \times 400$ menit). Sebelum pelajaran dimulai, siswa sudah melaksanakan perintah guru melakukan warming up, pereganggan statis dan dinamis, jogging keliling lapangan bola voli 3 kali. Sebelum guru mengontrol siswa dalam melakukan passing atas bola voli, guru membuka pelajaran dan menyampaikan tujuan pembelajaran yang ingin dicapai, dalam pertemuan ini dan menjelaskan teori passing atas bola voli. Dengan bentuk-bentuk posisi sikap permulaan, sikap saat memainkan bola dan sikap gerakan lanjutan. Setelah guru menyampaikan materi, guru

melontarkan pertanyaan-pertanyaan kepada siswa tentang gerakangerakan yang sudah dilakukan siswa dan mencari kesesuaian bentuk gerakan. Kegiatan pembelajaran siklus I diakhiri dengan penyampaian kesimpulan pelajaran yang dilakukan oleh guru bersama-sama dengan siswa. Proses pembelajaran ditutup dengan melakukan tes untuk melihat 
tingkat keberhasilan kompetensi yang dicapai siswa setelah materi disampaikan.

Hasil Observasi yang dilakukan memperhatikan kemampuan awal siswa kurang memuaskan, terbukti dengan hasil tes pertama siswa yang belum mencapai ketuntasan belajar yaitu 22 orang (55\%) dan yang mencapai ketuntasan belajar hanya 18 orang $(45 \%)$. Kemudian menurut dari hasil pengamatan antar siswa memiliki perbedaan yaitu yang belum mencapai ketuntasan 24 siswa $(60 \%)$ dan yang mencapai ketuntasan 16 siswa $(40 \%)$.

Secara umum berdasarkan hasil observasi passing atas bola voli menunjukkan hasil $56.83 \%$ siswa mengetahui gerakan dalam passing atas bola voli. Kemampuan yang menonjol terutama di dalam hasil sikap permulaan $(63 \%)$ menjadi yang tertinggi dan sikap saat memainkan bola (55\%). Hal ini menunjukkan bahwa siswa mendengarkan penjelasan guru di dalam proses pembelajaran. Tetapi masih ada beberapa siswa yang masih belum mengetahui gerakan lanjutan (52.5), hal ini dikarenakan pada waktu gerakan lanjutan passing atas bola voli tidak dilakukan dengan sempurna. Hal ini dikarenakan guru penjasnya tidak mengevaluasi setiap gerakan yang dibuat siswa.

Analisis Data I, Setelah Proses Observasi dan evaluasi dilakukan, selanjutnya dilakukan proses analisis dari data hasil belajar yang di dapatkan. Data hasil belajar siklus I yang di dapat kemudian di reduksi dan dipaparkan dalam bentuk tabel dengan menggunakan rumus:

$$
\mathrm{PPH}=\frac{B}{N} X 100 \%
$$

Keterangan:

PPH : Presentase Penilaian Hasil,

B : Skor yang diperoleh,

$\mathrm{N} \quad$ : Skor total maksimal (12), dengan kriteria:

$0 \% \leq \mathrm{KKM}<65 \% \quad$ = Siswa belum tuntas dalam belajar

$65 \% \leq \mathrm{KKM} \leq 100 \% \quad$ = Siswa sudah tuntas dalam belajar

Dari data yang diperoleh terlihat bahwa kemampuan awal (pre-test) sebelum diberi pembelajaran gaya mengajar resiprokal dengan menggunakan media simpai dalam melakukan passing atas bola voli masih tergolong rendah, dari 40 siswa terdapat 8 siswa yang masih mendapat nilai tingkat ketuntasan belajar, sedangkan 32 siswa belum mencapai tingkat ketuntasan belajar. Selanjutnya dilakukan pemberian gaya mengajar resiprokal dengan menggunakan media simpai pada proses belajar, dari 40 siswa terdapat 18 siswa $(45 \%)$ yang telah mendapat nilai ketuntasan dalam belajar sedangkan 22 siswa $(55 \%)$ belum mencapai tingkat ketuntasan belajar. Sedangkan menurut dari hasil pengamatan siswa dari 40 siswa terdapat 16 siswa $(40 \%)$ yang telah mendapat ketuntasan dalam belajar. Sedangkan 24 siswa $(60 \%)$ yang belum mencapai ketuntasan belajar.

Refleksi I, dari hasi analisis data siklus 1 didapat masih rendahnya hasil belajar passing atas siswa. Apalagi dalam gerak pelaksanaanya, sebagian siswa masih memiliki skor terendah. Didapat hasil belajar passing atas pada siklus pertama, dari 40 siswa terdapat 18 siswa (45\%) yang telah mencapai tingkat ketuntasan belajar dengan nilai rata-rata $56.83 \%$. sedangkan menurut dari hasil pengamatan siswa didapat hasil belajar passing atas pada siklus 1 terdapat 16 siswa (40\%) yang telah mencapai ketuntasan belajardengan nilai rata-rata $60.16 \%$, dapat disimpulkan bahwa hasil belajar siswa dari tes hasil belajar yang pertama masih rendah. Pada siklus 1 ini guru menemukan beberapa kesulitan yang dialami siswa seperti tersebut di atas. Untuk itu, maka perlu dilakukan perbaikan tindakan untuk siklus II.

\section{Pelaksanaan Siklus II}

Hasil Test pada siklus II yang dilakukan memperlihatkan kemampuan siswa meningkat jika dibandingkan dengan tes awal pada siklus I yaitu 35 siswa $(87.5 \%)$ yang mencapai ketuntasan belajar dan yang belum mencapai ketuntasan belajar sebanyak 5 siswa (12.5\%). Sedangkan menurut hasil pengamatan antar siswa memiliki perbedaan pada tes awal yaitu 340 siswa ( $85 \%$ ) yang mencapai ketuntasan belajar dan yang belum mencapai ketuntasan belajar sebanyak 6 siswa $(15 \%)$. Observasi, kegiatan belajar mengajar pada siklus II ini untuk mengamati setiap gerakan yang dilakukan oleh siswa. Hasil persentase observasi aktivitas siswa secara klasikal menunjukkan bahwa dalam siklus II ini proses belajar mengajar berjalan lebih baik jika dibandingkan dengan siklus I. Jika pada siklus I aktivitas siswa secara keseluruhan hanya 56.83\% kemudian meningkat pada siklus II menjadi $73.5 \%$. Analisis data II, setelah proses observasi dan evaluasi dilakukan, selanjutnya dilakukan proses analisis dari data hasil belajar yang di dapatkan. Data hasil belajar siklus II yang di dapat kemudian di reduksi dan dipaparkan dalam bentuk tabel dengan menggunakan rumus:

$$
\mathrm{PPH}=\frac{B}{N} X 100 \%
$$

Keterangan:

PPH : Presentase Penilaian Hasil,

B : : Skor yang diperoleh,

$\mathrm{N} \quad$ : Skor total maksimal (12), dengan kriteria:

$0 \% \leq \mathrm{KKM}<65 \% \quad=$ Siswa belum tuntas dalam belajar

$65 \% \leq \mathrm{KKM} \leq 100 \% \quad$ = Siswa sudah tuntas dalam belajar

Dari data hasil belajar siklus II yang didapat terlihat bahwa kemampuan siswa dalam melakukan tes hasil belajar secara klasikal sudah meningkat. Dari 40 siswa terdapat 35 siswa $(87.5 \%)$ yang telah mencapai ketuntasan belajar, sedangkan 5 siswa $(12.5 \%)$ yang belum mencapai ketuntasan belajar. Dalam siklus II ini proses belajar mengajar berjalan lebih baik jika dibandingkan dengan siklus I. Jika pada siklus I aktivitas siswa secara keseluruhan hanya $56.83 \%$ kemudian meningkat pada siklus II menjadi $73.5 \%$. Kemudian menurut hasil pengamatan antar siswa dari 40 siswa terdapat 34 siswa ( $85 \%$ ) yang telah mencapai ketuntasan belajar, sedangkan 6 siswa $(15 \%)$ yang belum mencapai ketuntasan belajar. Kemudian pada siklus I aktivitas siswa secara keseluruhan hanya $60.16 \%$ kemudian meningkat pada siklus II menjadi $72.08 \%$.

Dapat disimpulkan bahwa pembelajaran passing atas bola voli melalui penerapan gaya mengajar resiprokal dengan menggunakan media simpai yang tertuang pada hasil belajar I dan II mengalami peningkatan hasil belajar dan peningkatan ketuntasan belajar baik secara individual maupun klasikal. Hasil refleksi pengamatan setelah dilaksanakannya kegiatan belajar mengajar pada siklus II, diperoleh hasil bahwa adanya perbaikan hasil belajar passing atas bola voli pada siswa kelas VIII SMPN 40 Medan tahun ajaran 2015/2016 melalui penerapan gaya mengajar resiprokal dengan menggunakan media simpai, dengan persentase hasil belajar passing atas bola voli pada siklus I sebesar $45 \%$, kemudian meningkat menjadi $73,5 \%$ pada siklus II. Ini berarti bahwa siswa kelas VIII SMPN 40 Medan telah mencapai ketuntasan klasikal.

\section{Pembahasan}

Dari analisis data yang telah dilakukan dapat disimpulkan bahwa melalui penerapan gaya mengajar resipokal, siswa dapat memperbaiki hasil belajarnya pada pokok pembahasan passing atas bola voli. Dari analisis data juga dapat diketahui bahwa hasil belajar siswa dari tes hasil belajar sebelum menggunakan gaya mengajar resiprokal masih sangat rendah. Maka dilakukan penerapan gaya mengajar resiprokal pada proses pembelajaran. Dapat diketahui bahwa hasil belajar siswa dari tes hasil belajar siklus I menggunakan gaya mengajar resiprokal juga masih rendah. Maka perlu dilakukan perbaikan tindakan pada siklus II.

Dari hasil penelitian yang dilakukan, terlihat bahwa pada siklus I sebesar $45 \%$, kemudian meningkat menjadi $87.5 \%$ pada siklus II. Hasil belajar passing atas bola voli, siswa secara keseluruhan masih mencapai $56.83 \%$. Kemudian pada siklus II berdasarkan hasil refleksi ternyata membawa peningkatan menjadi $73.5 \%$. Sedangkan penilaian hasil dari pengamatan antar siswa dilakukan, terlihat bahwa pada siklus I sebesar $40 \%$, kemudian meningkat menjadi $85 \%$ pada siklus II. Hasil belajar passing atas bola voli, siswa secara keseluruhan masih mencapai $60.16 \%$. Kemudian pada siklus II berdasarkan hasil refleksi ternyata membawa peningkatan menjadi $72.08 \%$. Pada pejelasan diatas terlihat perbedaan dari hasil penelitian dengan hasil pengamatan antar siswa memiliki sedikit perbedaan, yaitu pada hasil belajar passing atas bola voli secara keseluruhan masih mencapai $56.83 \%$ sedangkan pengamatan antar siswa $60,16 \%$ dan pada siklus II juga memiliki sedikit perbedaan yaitu dari hasil peneliti $73.5 \%$ dan menurut hasil pengamatan antar siswa $72.08 \%$.

Perbedaan dari hasil peneliti dengan pengamatan antar siswa ini disebabkan karena persamaan dalam lembar instrument untuk peneliti dengan lembar pengamatan antar siswa tetapi dalam penilaianya sedikit berbeda yaitu lembar instrument untuk peneliti terdapat nilai skor, sedangkan pada lembar pengamat antar siswa tidak memiliki nilai skor tetapi memberi tanda chek $(\sqrt{ })$ pada saat melakukan dan tidak melakukan. 
Namun, apabila dilihat dari aspek penilaian gerakan lanjutan pada passing atas bola voli masih saja lebih rendah dari aspek yang lainnya. Pembelajaran passing atas bola voli tuntas setelah siklus II, in dikarenakan pemberian motivasi yang memicu semangat siswa untuk belajar. Sedangkan pada siklus I, siswa belum terbiasa dengan gaya mengajar yang diberikan guru, sehingga siswa perlu beradaptasi dengan gaya mengajar yang diberikan oleh guru. Salah satu penyebab ketidak berhasilan pencapaian tujuan program pengajaran yang direncanakan adalah kekurangan pengetahuan atau ketidak mampuan untuk memilih gaya mengajar yang digunakan sehingga anak didik tidak dapat mencapai tujuan pengajar.

Kendala yang dihadapi siswa dalam proses belajar mengajar yaitu karena kurang terbiasa dengan gaya mengajar yang diberikan guru. Karena selama ini gaya mengajar yang diterima siswa tidak pernah bervariasi. Oleh karena itu diharapkan peran serta lembaga pendidikan dan keguruan dalam menyiapkan tenaga-tenaga pendidik terutama guru yang akan memberikan pengajaran di dalam dan diluar kelas. Dalam artian pengajar harus mampu memilih dan menerapkan metode pembelajaran yang diprediksi akan lebih efektif untuk memudahkan siswa dalam belajar di kelas dan diluar kelas maupun belajar mandiri. Suksesnya seseorang dalam pelajarannya adalah sebagai hasil kesanggupan dan kemampuan yang ada pada siswa, sebagian lagi karena gaya mengajar dan belajar yang tepat dan sebagian lagi karena lingkungan.

Banyak gaya pembelajaran yang digunakan dalam pembelajaran termasuk pembelajaran penjas di sekolah, misalnya gaya mengajar resiprokal. Menurut (Supandi, 1992: 31) menyatakan bahwa "pada dasarnya gaya mengajar ini merupakan teori umpan balik atau feedback." Seluruh siswa bertanggung jawab mengobservasi teman dan memberikan umpan balik serta memberikan koreksi dari setiap gerakan yang dilakukan. Dengan kebebasan yang diberikan oleh guru, siswa dituntut lebih mandiri dan kreatif serta mempunyai rasa tanggung jawab yang besar karena peranan guru sangat diminimalisir dalam gaya ini.

Dalam gaya ini guru mempersiapkan dan menjelaskan tugas yang harus dilakukan oleh siswa, kriteria evaluasi yang diberikan guru berfungsi untuk menentukan bahwa gerakan yang dilakukan oleh pasangnya itu suah sesuai dengan rujukan yang ada. Lembaran kerja disini merupkan sumber belajar bagi siswa, jadi harus jelas, mudah diterima dan ditelaah sehingga tidak ada kesalahan dalam menafsir deskripsi gerakan atau pokok bahasan yang tertera dalam lembar kerja.

\section{Simpulan dan Saran}

Sebagai kesimpulan dalam penelitian ini adalah bahwa gaya mengajar Resiprokal menggunakan media simpai memberikan pengaruh terhadap perbaikan hasil belajar passing atas bola voli siswa SMPN 40 Medan tahun ajaran 2015/2016. Nilai persentase rata-rata siswa pada pre-test adalah $51 \%$ (Tidak Tuntas), pada post-test I nilai rata-rata siswa meningkat menjadi $56.83 \%$ (Tidak Tuntas), dan pada pelaksanaan posttest II nilai rata-rata siswa telah mencapai $73.5 \%$ (Tuntas).

Berdasarkan kesimpulan di atas, maka peneliti menyarankan sebagai berikut: (a) Gaya mengajar resiprokal merupakan gaya belajar yang dapat dipergunakan dalam meningkatkan hasil belajar siswa khususnya pada passing atas dalam permainan Bola Voli. (b) Bagi guru, calon guru dan mahasiswa khususnya guru pendidikan jasmani hendaknya menggunakan gaya mengajar yang tepat sehingga hasil belajar siswa dapat terus ditingkatkan.

\section{Daftar Pustaka}

Arikunto, S, 2006. Prosedur Penelitian. Jakarta: Rineka Cipta

Moston Musca, 1994. Teaching Physical Education. Third Edition.

Sydney Colombus Toronto. London: Merill Publishing Company

Sudjana, 2005. Metode Statistika. Bandung: Tarsito

Supandi, 1992. Strategi Belajar Mengajar Pendidikan Jasmani dan Kesehatan. Jakarta: DEPDIKBUD

Verayanti, P. 2011, hakikat, fungsi, dan peranan media pembelajaran (Online),

http://v3dolphin15.blogspot.com/2011/06/hakikat-fungsi-dan-peranan- media.html, (diakses 18 Juli 2012) 
JOURNAL OF SPORT SCIENCE AND EDUCATION (JOSSAE) VOL: 2, NO: 1 APRIL (2017)

Journal homepage: http://journal.unesa.ac.id/index.php/jossae/index 